\title{
SEDIMENTATION STUDY IN A RESERVOIR USING REMOTE SENSING TECHNIQUE
}

\author{
NiniJA MERINA, R. ${ }^{*}$-SASHIKKUMAR, M. C. ${ }^{2}-$ RIZVANA, N. $^{3}-$ AdLIN, R. ${ }^{4}$ \\ ${ }^{1}$ University college of Engineering, Nagercoil, Tamilnadu,India. \\ ${ }^{2}$ University College of Engineering, Dindigul, Tamilnadu, India. \\ ${ }^{3}$ University college of Engineering, Nagercoil, Tamilnadu,India \\ ${ }^{4}$ Anna university Chennai, Tamilnadu, India. \\ *Corresponding author: \\ e-mail:ninijajain@gmail.com \\ (Received $1^{\text {st }}$ Mar 2016; accepted $19^{\text {th }}$ Jul 2016)
}

\begin{abstract}
Reservoir sedimentation is a severe problem faced by dams caused due to soil erosion which is almost immeasurable at source and occurs in the catchment areas of the reservoirs. The present study describes the evaluation of sedimentation carried out for Vaigai reservoir situated in Tamil Nadu, India. Vaigai reservoir nourishes the inhabitants through water storage and supply for irrigation and water power. Nowadays, capacity loss occurs in the reservoir due to sedimentation. As it is highly tedious and uneconomical to do hydrographic surveys, the frequentness in finding the sediment yield becomes impossible. But the recent application of remote sensing and GIS technologies in the field of Civil Engineering make it possible. The Satellite Remote Sensing (SRS) method for prediction of reservoir sedimentation uses directly the water-spread area of the reservoir at a particular elevation on the date of pass of the satellite. With known area and the difference in level of water, the capacity and thereby the loss in capacity of the reservoir due to sedimentation can also be estimated. This paper illustrates the prediction of sedimentation at Vaigai reservoir using remote sensing and ArcGIS.
\end{abstract}

Keywords: sedimentation, remote sensing, reservoir, water spread area, capacity

\section{Introduction}

Reservoirs are built across rivers for the purpose of irrigation, water supply, power generation, discharge regulation and flood control. A reservoir will generally be located towards the end of a large watershed and receives inflows from major rivers (Jørgensen et al., 2005). On the other hand, reservoirs have a shorter residence time but a much larger watershed which can be more difficult to control (Randolph, 2004). Rainfall, runoff, snowmelt, and river channel erosion provide a continuous supply of sediment that is hydraulically transported and deposited in rivers and streams. The major advantages of dams are in flood control and in transferring water to areas with deficit of water (Wang et al., 2003; Mukherjee et al., 2007; Goel et al., 2002). There are many reservoirs that can no longer perform their design functions because much of their original active storage volume has been filled by sediment (Ijam and Al-Mahamid, 2012). The transported silt eventually gets deposited at different levels of a reservoir and reduces its storage capacity (Goel et al., 2002; Jain et al., 2002; Sreenivasulu and Udayabaskar, 2010). When the river flow enters a reservoir, due to the very low velocity in reservoirs, they tend to be very efficient sediment traps. Hence transport capacity is reduced and the sediment load is deposited in the reservoir. This deposition which takes place gradually reduces the active capacity of the reservoir and fails to 
provide the outputs of water with passage of time. Despite the fact that soil erosion can be caused by geomorphologic process, accelerated soil erosion is principally favored by human activities. Rapid population growth, deforestation, un- suitable land cultivation, uncontrolled and overgrazing have resulted in accelerated soil erosion in the world principally in developing countries like Ethiopia (Adebe and Sewnet, 2014; Tamene et al., 2006). All reservoirs formed by dams on natural rivers are subject to some degree of sediment inflow and deposition. Worldwide, around 40,000 large reservoirs suffer from sedimentation and it is estimated that between $0.5 \%$ and $1 \%$ of the total storage capacity is lost per year. Therefore, the amount of sedimentation all through the life of the project needs to be estimated, so that suitable conservation measures can be taken. Periodical capacity surveys of the reservoir help in assessing the rate of sedimentation and reduction in storage capacity (Jeyakanthan and Sanjeevi, 2013). A Geographical Information System (GIS) can be used to model bathymetry and the spatial distribution of sediments (Evans et al., 2002). Several attempts have been made to calculate the quantity of sediment using remote sensing technology (Yeo et al., 2014; Narasayya et al., 2013; Sri Sumantyo et al., 2012).Using the Remote Sensing techniques, it has become very efficient and convenient to quantify the sedimentation in a reservoir and to assess its distribution and deposition pattern (Narasayya et al., 2013). Remote sensing technology, offers data acquisition over a long period of time and broad spectral range, can provide synoptic, repetitive and timely information regarding the sedimentation characteristics in a reservoir. Water spread area of the reservoir for a particular elevation can be obtained very accurately from the satellite data. Reduction if any, in the water spread area for a particular elevation indicates deposition of sediment at that level. When it is integrated over a range of elevations using multi-date satellite data enables computing volume of storage lost due to sedimentation.

\section{Materials and methods}

\section{Study area}

The Vaigai Dam is built across the Vaigai River in Periyar Vaigai Basin near Andipatti, in the Theni district of Tamil Nadu, Southern India as shown in Figure 1.

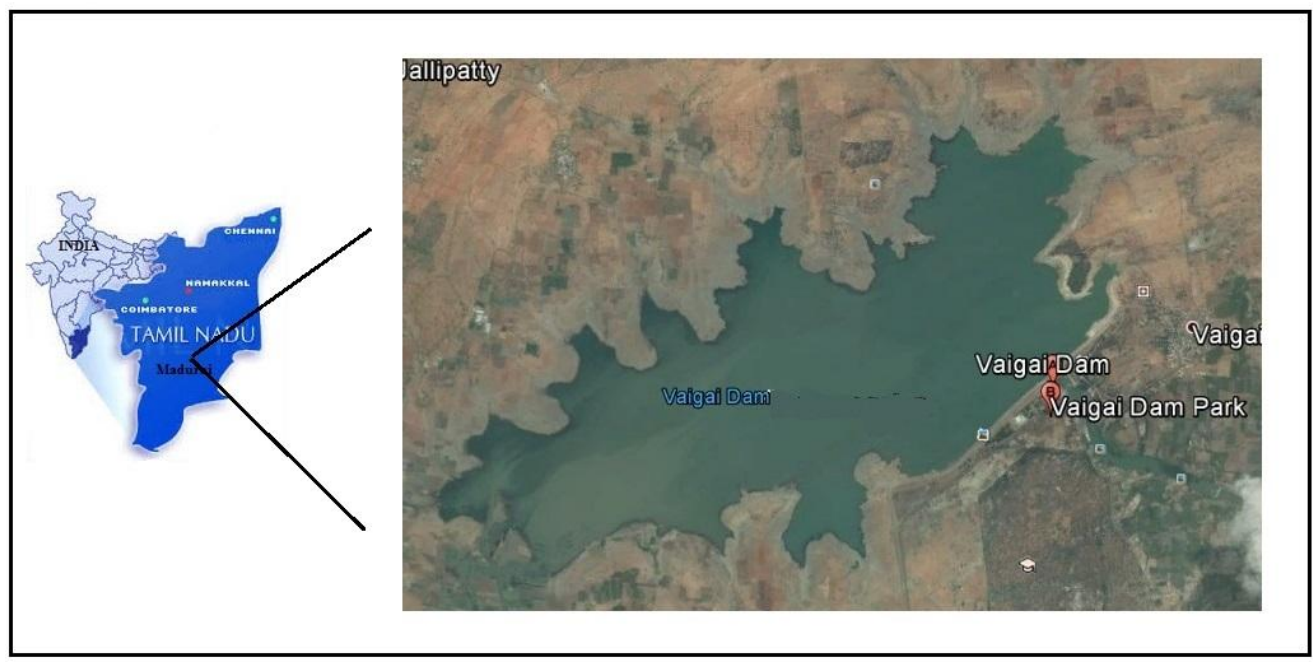

Figure 1. Location Map of Vaigai Reservoir 
It is situated between $9^{0} 30^{\prime}$ and $10^{\circ} 10^{\prime}$ North Latitudes and $77^{\circ} 10^{\prime}$ and $77^{\circ} 40^{\prime}$ East Longitude. The Vaigai reservoir project get started on January $10^{\text {th }}, 1955$ and completed on September, 1958. This is a multipurpose reservoir. It provides water for irrigation to Madurai and Theni district, drinking water to Madurai and Andipatti as well as facilitates hydroelectric power generation to the extent of $6 \mathrm{MW}$. The catchment area comprises of Cumbum Valley, Varushanadu valley, Varushanadu hills and Western Ghats. The Central area is low lying and consists of fertile irrigated wetland. Vast stretch of denuded forest spreads over the watershed along the plains of Varushanadu hills. The total catchment area of the reservoir is 2255.127 sq. $\mathrm{km}$ and the FRL of the reservoir is $279.197 \mathrm{~m}$. The Live storage of the reservoir lies between RL $257.556 \mathrm{~m}$ and RL $279.197 \mathrm{~m}$. The dead storage capacity lies between RL $249.936 \mathrm{~m}$ and RL 257.556 $\mathrm{m}$. The Capacity of the reservoir at maximum water level is $194.785 \mathrm{Mm}^{3}$. The general climate of the watershed is sub-tropical with temperature varying from $30^{\circ} \mathrm{C}$ to $35^{\circ} \mathrm{C}$. During summer months of April to June the hot weather prevails. The catchment receives rainfall from both North East and South West monsoons. The rainfall during South West Monsoon is comparatively less as it is at rain shadow region. The annual maximum rainfall varies from $1017.5 \mathrm{~mm}$ to $1586.9 \mathrm{~mm}$. In general, the soils are of deep sandy loam with reddish colour. The area is built with Archean rocks, which compose of gneiss, mica, quartzite, granites and veins of pegmatites and quartz veins.

\section{Data used}

Satellite Images of IRS-P6 LISS-III at six overpass dates including $3^{\text {rd }}$ August 2009, $17^{\text {th }}$ March 2009, $10^{\text {th }}$ January 2012, $1^{\text {st }}$ April 2012, $5^{\text {th }}$ March 2005 and $18^{\text {th }}$ June 2005 , from which the water spread areas were computed. These images were obtained from National Remote Sensing Agency, Hyderabad, India. Accordingly the Survey of India toposheets of 1:50,000 scales were used (Narasayya et al., 2013). Report of Sedimentation studies done during the fourth capacity survey of Vaigai reservoir in the year 2000 was used. Elevation- Capacity - Sedimentation data for the years 1958, 1976, 1981 and 1983 are shown in Table 1. Water spread area map/ Base Map of scale 1:3960 and the water elevations of the reservoir at different dates were obtained from the Office of the Public works Department at Vaigai dam.

Table1. Sediment and Capacity data of Vaigai reservoir for the years 1958, 1976, 1981 and 1983

\begin{tabular}{|c|c|c|c|c|c|c|c|c|c|}
\hline $\begin{array}{c}\text { Sl. } \\
\text { No }\end{array}$ & $\begin{array}{c}\text { Elevation } \\
\text { in m }\end{array}$ & $\begin{array}{c}\text { Depth } \\
\text { from deep } \\
\text { bed level }\end{array}$ & $\begin{array}{c}\text { \% of } \\
\text { depth }\end{array}$ & $\begin{array}{c}\text { Capacity } \\
\text { in 1958 } \\
\text { in } \mathbf{M m}^{\mathbf{3}}\end{array}$ & $\begin{array}{c}\text { Capacity } \\
\text { in 1976 } \\
\text { in } \mathbf{M m}^{\mathbf{3}}\end{array}$ & $\begin{array}{c}\text { Capacity } \\
\text { in 1981 } \\
\text { in } \mathbf{M m}^{\mathbf{3}}\end{array}$ & $\begin{array}{c}\text { Capacity } \\
\text { in 1983 in } \\
\mathbf{M m}^{\mathbf{3}}\end{array}$ & $\begin{array}{c}\text { Sediment } \\
\text { Deposit of } \\
\mathbf{1 9 8 3} \text { in } \\
\mathbf{M m}^{\mathbf{3}}\end{array}$ & $\begin{array}{c}\text { \% of } \\
\text { Sediment }\end{array}$ \\
\hline 1 & 249.936 & 0.000 & 0.000 & - & - & - & - & - & - \\
\hline 2 & 257.556 & 7.620 & 26.041 & 1.456 & 0.079 & - & - & 1.456 & 6.499 \\
\hline 3 & 258.000 & 8.064 & 27.559 & 1.732 & 0.125 & - & - & 1.732 & 7.730 \\
\hline 4 & 260.000 & 10.064 & 34.394 & 3.583 & 0.536 & 0.186 & 0.194 & 3.389 & 15.126 \\
\hline 5 & 262.000 & 12.064 & 41.223 & 7.002 & 1.845 & 1.026 & 1.129 & 5.873 & 26.213 \\
\hline 6 & 264.000 & 14.064 & 48.064 & 12.115 & 4.906 & 3.295 & 3.466 & 8.649 & 38.603 \\
\hline 7 & 266.000 & 16.064 & 64.899 & 20.338 & 10.489 & 8.346 & 8.118 & 12.220 & 54.541 \\
\hline 8 & 268.000 & 18.064 & 61.734 & 31.988 & 19.634 & 16.885 & 16.010 & 15.978 & 71.314 \\
\hline 9 & 270.000 & 20.064 & 68.569 & 46.436 & 33.525 & 29.294 & 28.720 & 17.716 & 78.072 \\
\hline 10 & 272.000 & 22.064 & 75.404 & 67.867 & 52.102 & 47.515 & 47.249 & 20.618 & 92.024 \\
\hline 11 & 274.000 & 24.064 & 82.239 & 93.407 & 77.006 & 72.128 & 72.264 & 21.144 & 94.372 \\
\hline 12 & 276.000 & 26.064 & 89.074 & 126.093 & 109.567 & 104.494 & 104.739 & 21.359 & 95.381 \\
\hline 13 & 278.000 & 28.064 & 95.909 & 166.649 & 149.688 & 144.294 & 144.399 & 22.250 & 99.308 \\
\hline 14 & 279.197 & 29.261 & 100.00 & 194.785 & 178.191 & 172.439 & 172.380 & 22.405 & 100.000 \\
\hline
\end{tabular}

Source : Sedimentation survey report of vaigai reservoir 


\section{Review of past sedimentation surveys}

The reservoir sedimentation problem depends upon the parameters like type of catchment, nature of catchment, geology, slope and terrain, rainfall, climate, vegetal cover, human activities etc. No universal solution is available for tracking the sedimentation problem because every reservoir is having differences in the above said parameters. Hence it is necessary that every reservoir has to be surveyed periodically. After inception of the reservoir in 1958, the first, second, third and fourth surveys were carried out during 1976, 1981, 1983 and 2000 respectively under the Watershed Management Board Scheme. The comparative sedimentation survey report for the years 1958, 1976, 1981 and 1983 are listed in Table 1. The report of the fourth sedimentation survey carried out in the year 2000, including the water spread area and capacities of the reservoir at different water levels are listed in Table 2.

Table2. Capacity chart of vaigai reservoir for various elevations during the year 2000

\begin{tabular}{|c|c|c|c|}
\hline $\begin{array}{c}\text { Sl. } \\
\text { No }\end{array}$ & $\begin{array}{c}\text { Elevation in } \\
\mathbf{M}\end{array}$ & $\begin{array}{c}\text { Water spread area } \\
\text { in } \mathbf{~ M m}^{\mathbf{2}}\end{array}$ & $\begin{array}{c}\text { Capacity for the corresponding } \\
\text { elevation in } \mathbf{~ M m}^{\mathbf{3}}\end{array}$ \\
\hline 1 & 257.556 & 0 & - \\
\hline 2 & 258.000 & 0.0160 & 0.0036 \\
\hline 3 & 260.000 & 0.1060 & 0.1256 \\
\hline 4 & 262.000 & 0.3596 & 0.5366 \\
\hline 5 & 264.000 & 1.1560 & 1.9258 \\
\hline 6 & 266.000 & 2.8713 & 5.7732 \\
\hline 7 & 268.000 & 5.3031 & 13.8887 \\
\hline 8 & 270.000 & 7.7265 & 26.9800 \\
\hline 9 & 272.000 & 10.1010 & 44.7621 \\
\hline 10 & 274.000 & 13.6646 & 68.1768 \\
\hline 11 & 276.000 & 17.7530 & 99.7704 \\
\hline 12 & 278.000 & 21.6970 & 139.0925 \\
\hline 13 & 279.197 & 24.1524 & 166.5334 \\
\hline
\end{tabular}

\section{Methodology}

\section{Computation of water spread area of Vaigai reservoir}

The Survey of India (SOI) toposheets for the Vaigai reservoir have been obtained, scanned and geometrically corrected to represent correct geographical coordinates at each point. Satellite Images of IRS-P6 LISS-III have been georeferenced with respect to toposheets and mosaiced using Arc GIS 9.3.1. The drainage network (streams and tributaries) and the catchment have been identified from the mosaiced toposheet and updated from satellite imagery. The catchment was divided into subcatchments to find its water spread area. The work has been carried out using Digital Image Processing software Arc GIS. The digitally processed images of Vaigai Reservoir showing its water spread area for six overpass dates such as $3^{\text {rd }}$ August $2009,17^{\text {th }}$ March $2009,10^{\text {th }}$ January 2012, $1^{\text {st }}$ April 2012, $5^{\text {th }}$ March 2005 and $18^{\text {th }}$ June 2005 are shown in Figure 2.

Table 3 shows satellite-derived reservoir water spread areas for different satellite overpass dates along with the water levels of the reservoir at the corresponding dates collected from the Office of the Public Works Department at Vagai Dam. Figure 3 
shows the curve between elevation and water spread area obtained through remote sensing data. From Table 2, the water spread area at the intermediate elevations (reservoir elevations on the dates of satellite pass) of the sedimentation survey conducted in the year 2000, were obtained by linear interpolation. Using those details, the elevation-area curve for the year 2000 is plotted along with the details of satellite derived. Any shift in the curve will indicate the loss in capacity of the reservoir due to sedimentation. Such shift in the updated elevation- area curve of Vaigai reservoir shown in Figure 4 represents that there will be capacity loss in Vaigai reservoir due to sediment deposition.

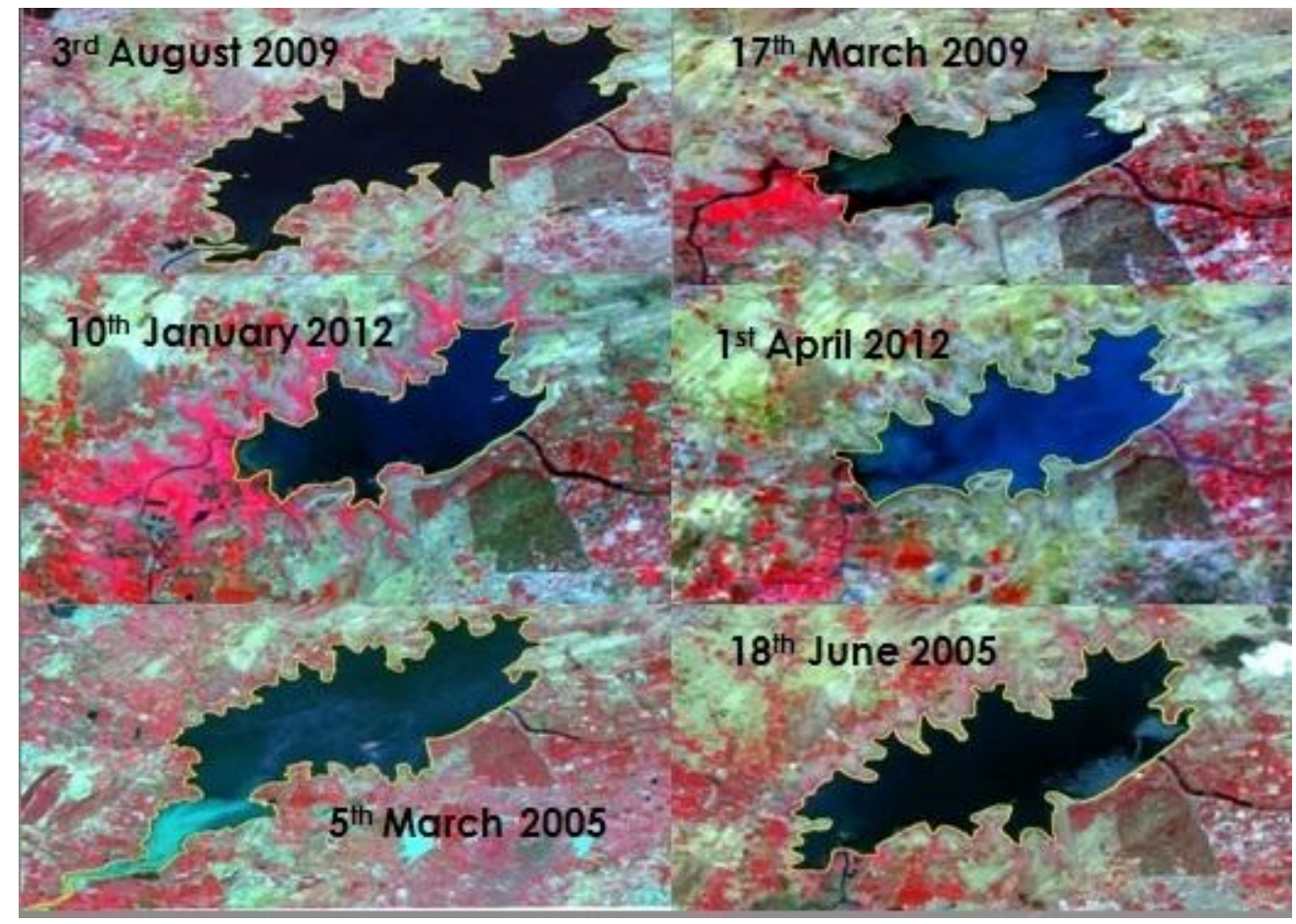

Figure 2. Digitally processed satellite images representing the water spread area for different overpass dates such as $5^{\text {th }}$ March 2005, $18^{\text {th }}$ June 2005, $17^{\text {th }}$ March 2009, $3^{\text {rd }}$ August 2009, $10^{\text {th }}$ January 2012, $1^{\text {st }}$ April 2012

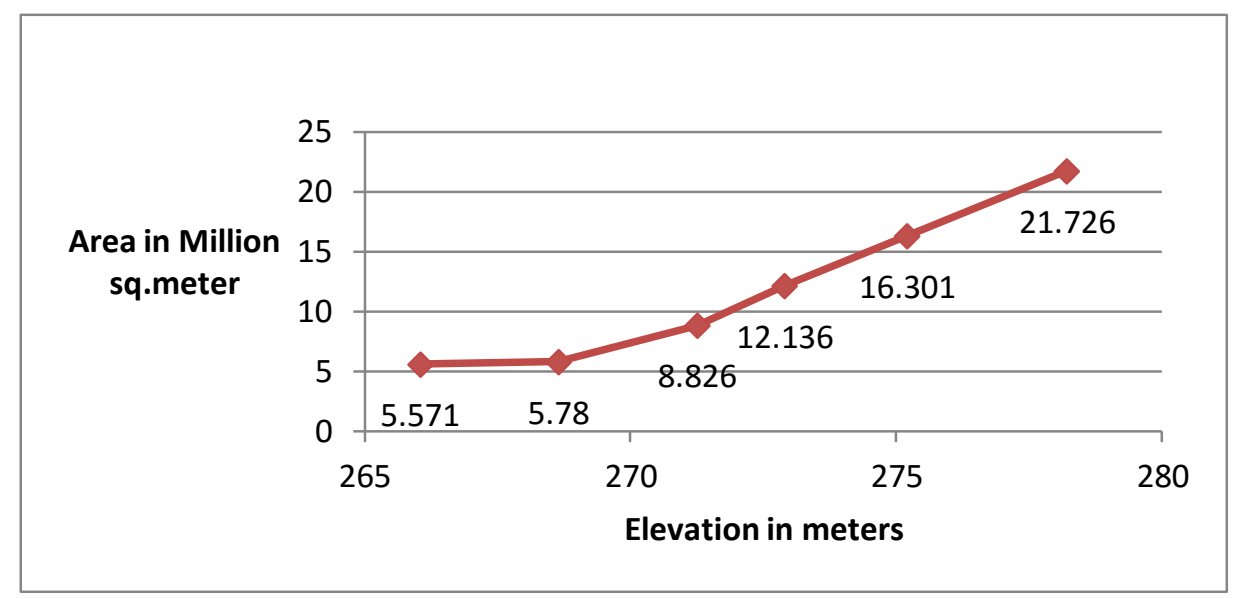

Figure 3. Satellite derived elevation-area curve (Areas noted are the water spread area for different satellite over pass dates and the corresponding elevations are plotted) 


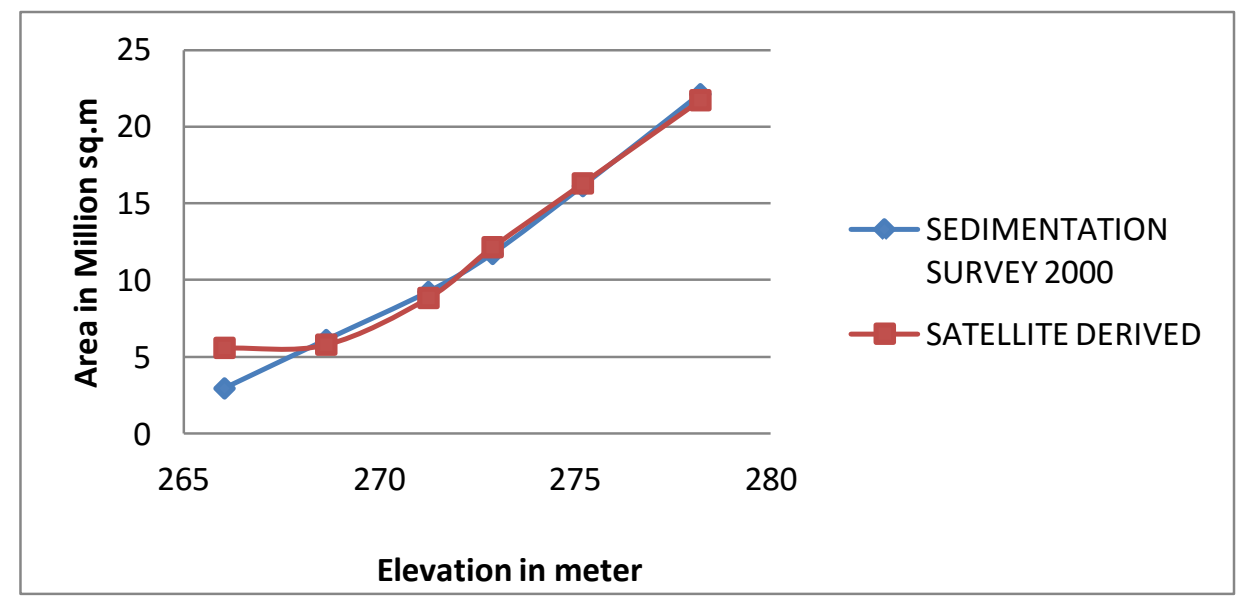

Figure 4. Comparative elevation-area curve for satellite derived data and sedimentation survey report

\section{Assessment of Vaigai reservoir capacity}

The reservoir capacity between two successive elevations can be assessed using the Cone formula:

$$
\mathbf{V}=\Delta \mathbf{H}\left(\mathbf{A}_{1}+\mathbf{A}_{2}+\sqrt{\mathbf{A}_{1}^{*} \mathbf{A}_{2}}\right) / 3
$$

Where V - Volume / Capacity between two consecutive elevations 1 and 2

$\mathrm{A}_{1}$ and $\mathrm{A}_{2}-$ Water spread areas of reservoir at elevations 1 and 2

$\Delta \mathrm{H}$ - difference between elevations 1 and 2

On adding the successive volumes between elevations the cumulative capacity above the lowest elevation can be calculated. Table 3 shows the capacities between elevations and cumulative capacities.

Table 3. Elevation, Water Spread Area and Capacity chart of Vaigai Reservoir for different satellite overpass dates

\begin{tabular}{|c|c|c|c|c|c|}
\hline $\begin{array}{c}\text { Sl. } \\
\text { No }\end{array}$ & $\begin{array}{c}\text { Satellite } \\
\text { Overpass } \\
\text { Dates }\end{array}$ & $\begin{array}{c}\text { Elevation } \\
(\mathbf{m})\end{array}$ & $\begin{array}{c}\text { Water } \\
\text { Spread } \\
\text { Area } \\
\mathbf{M m}^{2}\end{array}$ & $\begin{array}{c}\text { Capacity } \\
\text { between } \\
\text { elevations } \\
\mathbf{( M m}^{\mathbf{3})}\end{array}$ & $\begin{array}{c}\text { Cumulative } \\
\text { Capacity } \\
\mathbf{M m}^{\mathbf{3}}\end{array}$ \\
\hline 1 & $18-6-2005$ & 266.044 & 5.571 & 14.752 & - \\
2 & $17-3-2009$ & 268.644 & 5.780 & 18.936 & 14.752 \\
3 & $3-8-2009$ & 271.256 & 8.826 & 17.116 & 33.688 \\
4 & $1-4-2012$ & 272.896 & 12.136 & 32.669 & 50.804 \\
5 & $5-3-2005$ & 275.202 & 16.301 & 56.921 & 83.473 \\
6 & $10-1-2012$ & 278.206 & 21.726 & & 140.394 \\
\hline
\end{tabular}




\section{Estimation of Vaigai reservoir capacity loss}

The loss in capacity can be obtained by comparing the capacity data computed through remote sensing and capacity data obtained during $1^{\text {st }}$ and $4^{\text {th }}$ sedimentation survey of years 1958 and 2000 respectively. The comparison between elevationcapacity of the years 1958, 2000 and satellite derived data are shown in Table 4. The volume of sediment is the difference of capacity of years 1958 and 2000 and that obtained through satellite data, which can be treated as the loss of capacity due to sedimentation. The comparative capacity elevation curves for the years 1958, 2000 and satellite derived dates are shown as Figure 5. The shift in capacity curves in different years as compared to original capacity curve represents the loss in capacity or sediment deposited at different levels.

Table 4. Chart representing the Capacity loss due to sedimentation in Vaigai reservoir for the years 2000 and 2012

\begin{tabular}{|c|c|c|c|c|c|c|c|}
\hline $\begin{array}{c}\text { Sl. } \\
\text { No }\end{array}$ & $\begin{array}{c}\text { Observed } \\
\text { elevation (m) }\end{array}$ & $\begin{array}{c}\text { Water } \\
\text { Spread area } \\
\left(\mathbf{M m}^{\mathbf{2}}\right)\end{array}$ & \multicolumn{2}{|c|}{$\begin{array}{c}\text { Cumulative Capacity } \\
\left(\mathbf{M m}^{\mathbf{3}}\right)\end{array}$} & \multicolumn{2}{|c|}{$\begin{array}{c}\text { Capacity Loss } \\
\left(\mathbf{M m}^{\mathbf{3}}\right)\end{array}$} \\
\hline 1 & 257.556 & $\mathbf{R S} \mathbf{2 0 1 2}^{*}$ & $\mathbf{1 9 5 8}$ & $\mathbf{2 0 0 0}$ & $\begin{array}{c}\mathbf{R S}^{*} \\
\mathbf{2 0 1 2}\end{array}$ & $\mathbf{2 0 0 0}$ & $\begin{array}{c}\mathbf{R S}^{*} \\
\mathbf{2 0 1 2}\end{array}$ \\
\hline 2 & 266.044 & 5.571 & 20.594 & 5.951 & - & 14.643 & - \\
\hline 3 & 268.644 & 5.780 & 36.640 & 18.102 & 14.752 & 18.538 & 21.888 \\
\hline 4 & 271.256 & 8.826 & 59.894 & 38.147 & 33.688 & 21.747 & 26.206 \\
\hline 5 & 272.896 & 12.136 & 78.466 & 55.215 & 50.804 & 23.251 & 27.662 \\
\hline 6 & 275.202 & 16.301 & 113.051 & 87.164 & 83.473 & 25.887 & 29.578 \\
\hline 7 & 278.206 & 21.726 & 171.495 & 143.819 & 140.394 & 27.676 & 31.101 \\
\hline 8 & 279.197 & 23.183 & 194.785 & 166.533 & 162.620 & 28.252 & 32.164 \\
\hline
\end{tabular}

*Remote Sensing Data

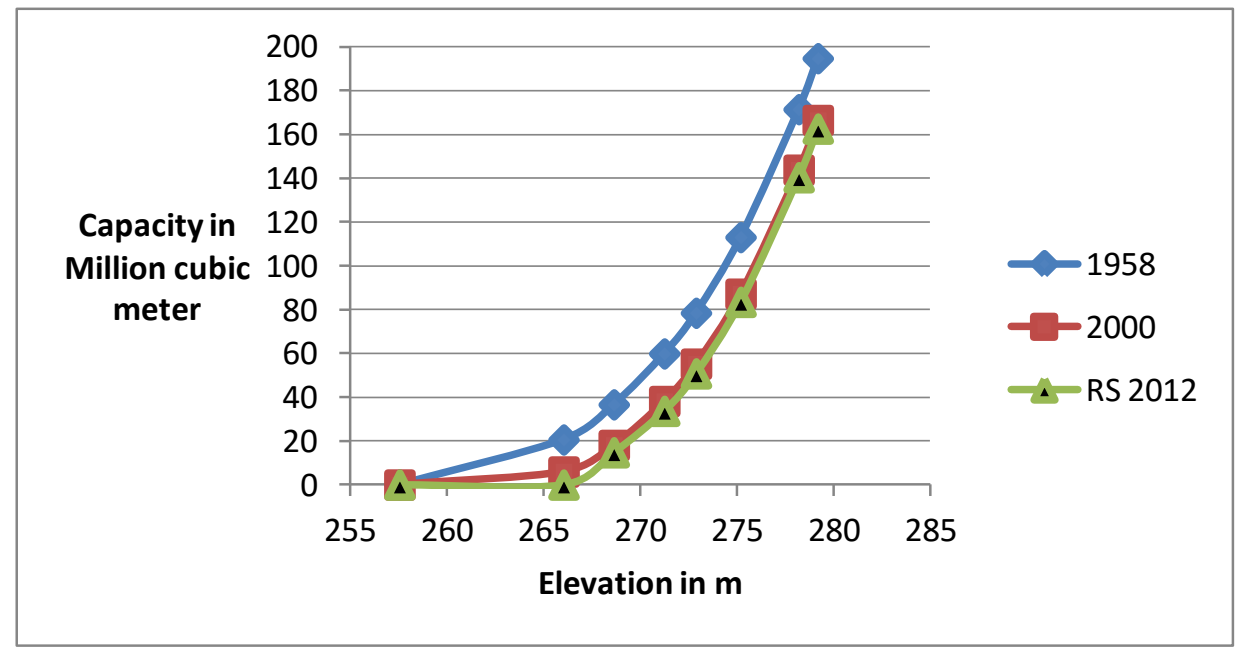

Figure 5. Comparison of cumulative capacities of Vaigai reservoir for the years 1958, 2000 and 2012 


\section{Results}

Based on the satellite remote sensing studies concerned with Vaigai reservoir, the following results have been concluded. The original capacity of Vaigai reservoir for the year 1958 was $194.785 \mathrm{Mm}^{3}$. As per the recent survey of 2000 , the original live storage capacity of $194.785 \mathrm{Mm}^{3}$ reduced to $166.533 \mathrm{Mm}^{3}$ i.e. by $14.50 \%$. Now, the capacity found out in this present study for the year 2012 was $162.620 \mathrm{Mm}^{3}$. Ultimately, the net sediment deposition between 1958 and 2012 is $32.164 \mathrm{Mm}^{3}$. Average annual silting load per sq. $\mathrm{km}$ of drainage area is $2.641 \times 10^{-4} \mathrm{Mm}^{3} / \mathrm{sq} . \mathrm{km} /$ year. From the above said results, following inferences can be made.

The gross storage capacity of Vaigai reservoir has reduced from $194.785 \mathrm{Mm}^{3}$ to 162.620 $\mathrm{Mm}^{3}$ till 2012. Vaigai reservoir has lost its capacity by $32.164 \mathrm{Mm}^{3}$ in the year 2012 since its inception, i.e., its total sediment yield is $32.164 \mathrm{Mm}^{3}$ which is greater than the sediment yield of the year 2000 , which was $28.252 \mathrm{Mm}^{3}$. The average annual silting rate for the years 1976, 2000 and 2012 are $8.519 \%, 14.504 \%$ and $16.512 \%$ respectively.

\section{Discussion}

The net sediment deposition of the reservoir from the year of inception ( i.e ) 1958 to 2012 is $32.164 \mathrm{Mm}^{3}$. From Table 4, it is clear that for various elevations, there is change in capacity for different years. Therefore it is understood that definite relationship exists between reservoir shape and the sediment accumulation at various depths since its impoundment (Narasayya et al., 2013). As per the present study, average annual silting rate of vaigai reservoir is increasing day by day and it is $16.512 \%$ in 2012. High sedimentation rates were observed where there is steep slope and high rain fall which indicates that sedimentation rate is highly dependent on slope factor and rain fall intensity (Alemaw et al., 2013). If it goes on increasing, it reduces the useful life of the reservoir. Sediment entering the reservoir can be minimized by vegetative treatment and structural intervention. Strong awareness has to be created both for lower land users who are engaged in intense irrigation farming and upper land users for suitable land management practices to protect the water shed (Gelagay and Minale, 2016).

If desilting is proposed the approximate cost will be Rs. 238 crores whereas for the construction of new dam, the cost will be Rs.1460 crores. So, the cost of desilting is only $16.20 \%$ of the cost of construction of new dam. Hence, to reduce soil erosion, urban development authorities must take environmental preservation measures into account (Park et al., 2011).

Acknowledgements. The authors gratefully acknowledge the help provided by Institute of Remote Sensing, Anna University, Chennai. The authors are also thankful to the Vaigai reservoir authorities for providing sedimentation data and water levels on different dates and other relevant information needed for the study. The authors would also like to thank the anonymous referees for contributing insightful remarks and useful suggestions which led to improve the manuscript substantially.

\section{REFERENCES}

[1] Adebe, Z. D., Sewnet, M. A. (2014): Adoption of soil conservation practices in North Achefer District, Northwest Ethiopia - Chinese Journal of Population Resources and 
Environment 12(3): 261-268., http://dx.doi.org/10.1080/10042857.2014.934953.

[2] Alemaw, B. F., Majauale, M., Simalenga, T. (2013): Assessment of Sedimentation Impacts on Small Dams - A Case of Small Reservoirs in the Lotsane Catchment. Journal of Water Resource and Protection 5: 1127-1131.

[3] Evans, J.E., Levine, N.S., Roberts, S.J., Gottgens, J.F., Newman, D.M. (2002): Assessment using GIS and sediment routing of the proposed removal of Ballville dam, Sandusky River, Ohio - Journal of the American Water Resources Association 38(6): 1549-1565.

[4] Gelagay, H.S., Minale, A.S. (2016): Soil loss estimation using GIS and Remote sensing techniques: A case of Koga watershed, Northwestern Ethiopia - International Soil and Water Conservation Research 4(2):126-136., http://dx.doi.org/10.1016/ j.iswcr.2016.01.002i

[5] Goel, M.K., Jain, S.K., Agarwal, P.K. (2002): Assessment of sediment deposition rate in Bargi Reservoir using digital image processing - Hydrological sciences journal 47(S1): S81-S92.

[6] Ijam, A. Z., Al-Mahamid, M. H. (2012): Predicting Sedimentation at Mujib Dam Reservoir in Jordan. - Jordan Journal of Civil Engineering 6(4): 448-463.

[7] Jain, S.K., Singh, P., Seth, S.M. (2002): Assessment of sedimentation in Bhakra Reservoir in the western Himalayan region using remotely sensed data - Hydrological Sciences Journal 47(2): 203-212.

[8] Jeyakanthan, V.S., Sanjeevi, S. (2013): Capacity survey of Nagarjuna Sagar reservoir, India using Linear Mixture Model (LMM) approach - International Journal of Geomatics and Geosciences 4(1): 186-194.

[9] Jørgenson, S.E., Loffler, H., Rast, W., Straskraba, M. (2005): Lake and reservoir management ( $1^{\text {st }}$ ed.). - Boston, MA: Elsevier Science.

[10] Mukherjee, S., Veer, V., Tyagi, S.K., Sharma, V. (2007): Sedimentation Study of Hirakud Reservoir through Remote Sensing Techniques - J. Spat. Hydrol. 7: 122-130.

[11] Narasayya, K., Roman, U.C., Sreekanth, S., Jatwa, S. (2013): Assessment of Reservoir Sedimentation Using Remote Sensing Satellite Imageries - Asian J. Geoinformatics.

[12] Park, S., Oh, C., Jeon, S., Jung, H., Choi, C. (2011): Soil erosion risk in Korean Watersheds, assessed using the revised universal soil loss equation - Journal of Hydrology 399(3-4): 263-273.

[13] Randolph, J. (2004): Environmental land use planning and management Washington D.C.: Island Press.

[14] Sreenivasulu, V., Udayabaskar, P. (2010): An integrated approach for prioritization of reservoir catchment using remote sensing and geographic information system - Geocarto International 25(2): 149-168.

[15] Tamene, L., Park, S. J., Dikau, R., Vlek, P.L.G. (2006): Analysis of factors determining sediment yield variability in the high lands of Northern Ethiopia - Geomorphology 76(1-2): 76-91.

[16] Wang, X., Shao, X., Li, D-X. (2003): Sediment Deposition Pattern and Flow Conditions in the Three Gorges Reservoir: A Physical Model Study - Tsinghua Sci. Technol. 8(6): 708-712.

[17] Sri Sumantyo, J. T., Shimada, M., Mathieu, P-P., Putri, R. F. (2012): Dinsar Technique for Retrieving The Volume of Volcanic Materials Erupted by Merapi Volcano - IEEE International Geoscience and Remote Sensing Symposium (IGARSS), pp: 1302-1305.

[18] Yeo, I-Y., Lang, M., Vermote, E. (2014): Improved Understanding of Suspended Sediment Transport Process Using Multi-Temporal Landsat Data: A Case Study From the Old Woman Creek Estuary (Ohio). - IEEE J. Sel. Top. Appl. Earth Obs. Remote Sens. 7(2): 636-647. 